E-JURNAL EKONOMI DAN BISNIS UNIVERSITAS UDAYANA
Available online at https://ojs.unud.ac.id/index.php/EEB/index
Vol. 10 No. 09, September 2021, pages: 789-798
e-ISSN: 2337-3067

\title{
PENGARUH KONSERVATISME AKUNTANSI, CAPITAL INTENSITY, DAN INVESTMENT OPPORTUNITY SET PADA TAX AVOIDANCE
}

\section{Desi Kusuma Dewi ${ }^{1}$ Naniek Noviari ${ }^{2}$}

\begin{tabular}{l}
\hline \multicolumn{1}{c}{ Article history: } \\
\hline Submitted: 11 Juni 2021 \\
Revised: 25 Juni 2021 \\
Accepted: 5 Juli 2021 \\
\hline
\end{tabular}

Keywords:

Accounting Conservatism; Capital Intensity; Investment Opportunity Set; Tax Avoidance;

\section{Kata Kunci: \\ Konservatisme Akuntansi; Capital Intensity; \\ Investment Opportunity Set; Tax Avoidance;}

\section{Koresponding: \\ Fakulas Ekonomi dan Bisnis Universitas Udayana, Bali, Indonesia \\ Email: desikusumadewii@gmail.com}

Abstract
Tax avoidance is one way to avoid taxes legally that does not violate
tax regulations. Tax avoidance can be said to be a complicated and unique
issue because on one hand it is permissible, but on the other hand it is
undesirable. Although it does not violate tax regulations, these actions are
basically not in accordance with tax laws and make state tax revenues not
optimal. This study aims to determine the effect of accounting conservatism,
capital intensity, and investment opportunity set on tax avoidance. The
population of this study focuses on mining companies on the Indonesia
Stock Exchange for the $2016-2019$ period, with total of 47 companies. The
number of companies that were selected as samples were 11 companies,
hence 44 observations were obtained during the study period. The analysis
technique used in this research is multiple linear regression. The results of
the analysis shows accounting conservatism has no effect on tax avoidance,
capital intensity has a positive effect on tax avoidance, and the investment
opportunity set has a negative effect on tax avoidance. This shows
accounting conservatism is not a causal variable that influence companies
to carry out tax avoidance and the higher the capital intensity of the
company, the higher the tax avoidance action taken by the company and the
higher the investment opportunity set of the company, the lower the tax
avoidance action taken by the company.

Abstrak
Tax avoidance adalah salah satu cara untuk menghindari pajak secara
legal yang tidak melanggar peraturan perpajakan. Tax avoidance ini dapat
dikatakan persoalan yang rumit dan unik karena disatu sisi tax avoidance
diperbolehkan, tetapi di sisi lain hal ini tidak diinginkan. Penelitian ini
bertujuan untuk mengetahui pengaruh konservatisme akuntansi, capital
intensity, dan investment opportunity set pada tax avoidance. Populasi
penelitian ini difokuskan pada perusahaan pertambangan di Bursa Efek
Indonesia periode 2016-2019 yang berjumlah 47 perusahaan. Jumlah
perusahaan yang terpilih menjadi sampel sebanyak 11 perusahaan, sehingga
diperoleh 44 amatan selama periode penelitian. Teknik analisis yang
digunakan dalam penelitian ini adalah regresi linear berganda. Hasil analisis
menunjukkan bahwa konservatisme akuntansi tidak berpengaruh pada tax
avoidance, capital intensity berpengaruh positif pada tax avoidance, dan
investment opportunity set berpengaruh negatif pada tax avoidance. Hal ini
menunjukkan bahwa konservatisme akuntansi bukanlah variabel penyebab
yang mempengaruhi perusahaan untuk melakukan tax avoidance serta
semakin tinggi capital intensity perusahaan maka tindakan tax avoidance
yang dilakukan oleh perusahaan semakin tinggi dan semakin tinggi
investment opportunity set perusahaan maka tindakan tax avoidance yang
dilakukan oleh perusahaan semakin rendah.

Fakultas Ekonomi dan Bisnis Universitas Udayana, Bali, Indonesia ${ }^{2}$

Email: novikeinan@unud.ac.id 


\section{PENDAHULUAN}

Pajak merupakan penerimaan terbesar dalam APBN Indonesia, oleh karena itu pajak tetap menjadi fokus pemerintah. Pajak memiliki fungsi budgetair, yaitu berfungsi untuk membiayai pengeluaran-pengeluaran negara baik rutin maupun pembangunan. Seiring perkembangan waktu, kebutuhan dana negara semakin besar untuk pembangunan sehingga target pajak yang ditetapkan pemerintah perlu untuk ditingkatkan. Namun, dalam perpajakan sering terjadi target anggaran tidak dapat tercapai. Belum mampunya pemerintah merealisasikan penerimaan pajak secara maksimal menimbulkan pertanyaan apakah dari sisi wajib pajak terdapat beberapa praktik yang dilakukan untuk meminimalkan pajaknya atau memang pemungutan pajak yang dilakukan belum optimal (Wiguna \& Jati, 2017). Pemerintah terus berupaya dalam mengoptimalisasi penerimaan pajak, baik dengan melakukan penyesuaian tarif pajak penghasilan ( $\mathrm{PPh}$ ), ataupun dengan menerapkan program pengampunan pajak atau tax amnesty. Menurut Maitriyadewi \& Noviari (2020), program tax amnesty dianggap cukup efektif dalam mendorong penerimaan pajak tahun 2017. Walaupun mengalami peningkatan, realisasi penerimaan pajak belum mencapai target yang ditentukan. Seharusnya dengan adanya upaya-upaya pemerintah tersebut target penerimaan pajak dapat terealisasi.

Cahya Dewanti \& Sujana (2019) menyebutkan salah satu penyebab penerimaan pajak tidak optimal karena perusahaan tidak mendapatkan timbal balik secara langsung sehingga berencana untuk melalukan penghindaran pajak atau tax avoidance untuk mengurangi beban pajaknya. Hal ini dilakukan karena dengan membayar pajak maka kemampuan ekonomis perusahaan akan berkurang. Tax avoidance adalah upaya pengurangan utang pajak yang bersifat legal (lawful), sedangkan penggelapan pajak (tax evasion) adalah upaya pengurangan hutang pajak yang bersifat tidak legal (unlawful) (Xynas, 2011). Tax avoidance (penghindaran pajak) dilakukan perusahaan untuk meminimalisir pembayaran pajak dengan menggunakan peluang dalam peraturan perpajakan negara (Putra et al., 2018). Meskipun hal ini tidak menyalahi aturan, namun tidak sesuai dengan jiwa undangundang perpajakan serta dapat membuat penerimaan pajak negara menjadi tidak optimal.

Rosdiani \& Hidayat (2020) mengemukakan bahwa salah satu faktor yang mempengaruhi tax avoidance adalah konservatisme akuntansi. Konservatisme akuntansi adalah prinsip kehati-hatian manajemen perusahaan dalam mengakui pendapatan dan biaya untuk menghadapi segala risiko yang mungkin akan terjadi, bahwa sikap optimisme manajemen mengakui biaya atau rugi yang pasti akan terjadi dibandingkan keuntungan atau pendapatan di masa yang akan datang (Yulistian dkk., 2018). Konservatisme akuntansi akan menyebabkan penurunan nilai laba perusahaan yang dijadikan dasar untuk menghitung beban pajak perusahaan tersebut (Sundari \& Aprilina, 2017). Dengan semakin minimnya laba perusahaan maka beban pajak yang harus dibayarkan juga lebih rendah. Penelitian yang dilakukan oleh Adi \& Mildawati (2018) dan Rosdiani \& Hidayat (2020) menemukan bahwa konservatisme akuntansi berpengaruh positif pada tax avoidance.

Karakteristik sebuah perusahaan juga merupakan faktor yang dapat mempengaruhi perusahaan dalam melakukan tax avoidance, salah satunya yaitu capital intensity (Muzakki \& Darsono, 2015). Capital Intensity adalah seberapa besar perusahaan menginvestasikan asetnya pada aset tetap. Perusahaan yang memutuskan untuk berinvestasi dalam bentuk aset tetap dapat menjadikan biaya penyusutan sebagai biaya yang dapat dikurangkan dari penghasilan dan akan menyebabkan laba kena pajak perusahaan menjadi berkurang (Jama' \& Harnovinsah, 2017). Artinya semakin besar biaya penyusutan akan semakin kecil tingkat pajak yang harus dibayarkan perusahaan. Penelitian yang dilakukan oleh Anindyka dkk. (2018), Dwiyanti \& Jati (2019) dan Artinasari \& Mildawati (2018) menemukan bahwa capital intensity berpengaruh positif pada tax avoidance. 
Azharuddin (2016) menyebutkan faktor lain yang dapat menyebabkan penyebab perbedaan tarif pajak efektif pada tiap-tiap perusahaan adalah investment opportunity set (IOS). IOS adalah pilihan investasi yang dimiliki perusahaan dimasa yang akan datang. Perusahaan dengan IOS yang tinggi berarti lebih memanfaatkan peluang investasinya dan berusaha mendapatkan keuntungan yang besar dari investasi tersebut, sehingga akan mengurangi kemungkinan perusahaan untuk melakukan kegiatan penghindaran pajak. Penelitian terdahulu yang dilakukan oleh Firmansyah \& Bayuaji (2019) mendapatkan hasil bahwa IOS berpengaruh negatif pada tax avoidance.

Berdasarkan penjelasan rumusan masalah, dan penelitian-penelitian sebelumnya, dapat dirumuskan beberapa hipotesis penelitian sebagai berikut: $\mathrm{H}_{1}$ : Konservatisme Akuntansi berpengaruh positif pada Tax Avoidance; $\mathrm{H}_{2}$ : Capital Intensity berpengaruh positif pada Tax Avoidance; $\mathrm{H} 3$ : Investment Opportunity Set berpengaruh negatif pada Tax Avoidance.

\section{METODE PENELITIAN}

Penelitian ini memperlihatkan bagaimana pengaruh konservatisme akuntansi, capital intensity, dan investment opportunity set pada tax avoidance. Lokasi penelitian dilakukan pada perusahaan di sektor pertambangan yang terdaftar di Bursa Efek Indonesia (BEI) tahun 2016-2019 dengan mengakses data perusahaan berupa informasi laporan keuangan pada situs resminya di www.idx.co.id. Populasi dalam penelitian ini adalah seluruh perusahaan pertambangan yang terdaftar di Bursa Efek Indonesia pada periode 2016-2019. Sampel dalam penelitian ini adalah perusahaan pertambangan yang terdaftar di Bursa Efek Indonesia periode 2016-2019. Jenis data yang digunakan dalam penelitian ini adalah data kuantitatif. Sumber data pada penelitian ini menggunakan data sekunder, dari laporan keuangan dan laporan tahunan perusahaan sektor pertambangan yang terdaftar di Bursa Efek Indonesia periode 2016-2019 yang dipublikasikan dalam situs resmi Bursa Efek Indonesia www.idx.co.id. Metode penentuan sampel yang digunakan dalam penelitian ini adalah metode non-probability sampling dengan teknik purposive sampling, yaitu dengan memilih sampel berdasarkan kriteria tertentu yang sesuai dengan tujuan penelitian. Metode pengumpulan data yang digunakan dalam penelitian ini adalah metode non participant observation, dimana dalam metode ini peneliti melakukan pengamatan pada data laporan keuangan dan laporan tahunan (annual report) perusahaan pertambangan yang terdaftar di Bursa Efek Indonesia (BEI) periode 2016-2019. Teknik analisis data yang digunakan dalam penelitian ini adalah analisis statistik deskriptif dan analisis regresi liniear berganda. Sebelum dilakukan analisis regresi linear berganda, dilakukan uji asumsi klasik yang terdiri dari uji normalitas, uji multikolinearitas, uji heteroskedatisitas, dan uji autokorelasi. Kemudian untuk mengetahui apakah variabel independen berpengaruh pada variabel dependen baik secara simultan ataupun parsial dilakukan uji koefisien determinasi, uji $\mathrm{F}$ dan uji $\mathrm{t}$.

\section{HASIL DAN PEMBAHASAN}

Populasi yang digunakan dalam penelitian ini adalah perusahaan pertambangan yang terdaftar di BEI selama tahun 2016-2019. Metode penentuan sampel yang digunakan dalam penelitian ini adalah metode non-probability sampling dengan teknik purposive sampling, yaitu dengan memilih sampel berdasarkan kriteria tertentu. Berdasarkan metode tersebut, maka diperoleh 11 perusahaan pertambangan yang menjadi sampel penelitian. Proses penentuan sampel dapat dilihat pada Tabel 1 .

Pengaruh Konservatisme Akuntansi, Capital Intensity, dan Investment Opportunity Set pada Tax Avoidance, 
Tabel 1.

Proses Penentuan Sampel

\begin{tabular}{clc}
\hline No & \multicolumn{1}{c}{ Keterangan } & $\begin{array}{c}\text { Jumlah } \\
\text { Perushaan }\end{array}$ \\
\hline 1 & $\begin{array}{l}\text { Perusahaan pertambangan yang terdaftar di Bursa Efek Indonesia (BEI) } \\
\text { periode 2016-2019 dan tidak didelisting selama periode penelitian; }\end{array}$ & 47 \\
2 & $\begin{array}{l}\text { Perusahaan yang tidak mempublikasikan laporan keuangan dan laporan } \\
\text { tahunan (annual report) periode 2016-2019 secara berturut-turut; }\end{array}$ & $(8)$ \\
3 & Perusahaan mengalami kerugian selama periode 2016-2019; & $(20)$ \\
4 & Perusahaan dengan nilai Cash Effective Tax Rate (CETR) lebih dari & $(6)$ \\
& Satu. & 13 \\
& Jumlah sampel & $(2)$ \\
\hline & Outlier & 11 \\
& Jumlah sampel & 4 \\
\hline & Tahun observasi & $\mathbf{4 4}$ \\
\hline
\end{tabular}

Sumber : Data diolah, 2021

Berdasarkan Tabel 1, diketahui bahwa jumlah perusahaan pertambangan yang terdaftar di Bursa Efek Indonesia (BEI) selama tahun 2016 hingga 2019 yang memenuhi kriteria sampel adalah 11 perusahaan. Perusahaan yang tidak menerbitkan laporan keuangan dan laporan tahunan secara berturut-turut selama tahun 2016 hingga 2019 adalah 8 perusahaan. Terdapat 20 perusahaan pertambangan yang mengalami kerugian. Serta 6 perusahaan pertambangan yang memiliki nilai Cash Effective Tax Rate (CETR) lebih dari satu. Dalam penelitian ini, peneliti menghapus data-data outlier agar data tersebar secara normal. Hal ini menyebabkan perusahaan yang diteliti berkurang menjadi 11 perusahaan dengan total penelitian menjadi 44 pengamatan.

Tabel 2.

Hasil Analisis Statistik Deskriptif

\begin{tabular}{lccccc}
\hline & N & Minimum & Maximum & Mean & Std. Deviation \\
\hline Tax Avoidance & 44 & 0,0472 & 0,7930 & 0,366191 & 0,1569766 \\
Konservatisme Akuntansi & 44 & $-0,2855$ & 0,0839 & $-0,021402$ & 0,0671091 \\
Capital Intensity & 44 & 0,0590 & 0,5555 & 0,263284 & 0,1194006 \\
Investment Opportunity Set & 44 & 0,5593 & 2,2019 & 1,156734 & 0,4089052 \\
Valid N (listwise) & 44 & & & &
\end{tabular}

Sumber: Data diolah, 2021

Hasil analisis deskriptif pada tabel masing-masing variabel penelitian dapat dideskripsikan sebagai berikut: Variabel Tax Avoidance (Y), Tax avoidance yang diproksikan dengan CETR menunjukkan nilai minimum 0,0472 yang dimiliki oleh PT Harum Energy Tbk. pada tahun 2016, artinya tax avoidance dalam perusahaan ini cenderung tinggi. Nilai maksimum dari variabel tax avoidance adalah 0,7930 yang dimiliki oleh PT Delta Dunia Makmur Tbk. pada tahun 2019. Hal ini berarti tingkat tax avoidance pada perusahaan ini cenderung rendah. Nilai rata-rata (mean) dari variabel tax avoidance adalah sebesar 0,366191 dan nilai standar deviasi sebesar 0,1569766 menunjukkan bahwa standar penyimpangan data terhadap nilai rata-ratanya sebesar 0,1569766.

Variabel Konservatisme Akuntansi $\left(\mathrm{X}_{1}\right)$, konservatisme akuntansi dalam penelitian ini diukur menggunakan model akrual Givoly and Hayn (2000). Semakin akrual bernilai negatif maka akan semakin konservatif akuntansi yang diterapkan. Berdasarkan hasil uji statistik deskriptif dapat

Pengaruh Konservatisme Akuntansi, Capital Intensity, dan Investment Opportunity Set pada Tax Avoidance, Desi Kusuma Dewi dan Naniek Noviari 
dijelaskan konservatisme akuntansi memiliki nilai minimum sebesar -0,2855 yang dimiliki oleh PT Toba Bara Sejahtra Tbk. pada tahun 2019. Hal ini menunjukan bahwa semakin konservatif akuntansi yang diterapkan perusahaan. Nilai maksimum dari konservatisme akuntansi sebesar 0,0839 yang dimiliki oleh PT Bukit Asam Tbk. pada tahun 2018. Nilai rata-rata (mean) sebesar -0,021402 dan nilai standar deviasi sebesar 0,0671091 menunjukkan bahwa standar penyimpangan data terhadap nilai rataratanya sebesar 0,0671091 .

Variabel Capital Intensity $\left(\mathrm{X}_{2}\right)$, capital intensity diukur dengan membandingkan total aset tetap dengan total aset. Variabel capital intensity memiliki nilai minimum sebesar 0,0590, memiliki arti bahwa aset tetap yang dimiliki perusahaan hanya sebesar 5,9\% dari total aset perusahaan secara keseluruhan. Perusahaan dengan nilai minimum ini dimiliki oleh PT Toba Bara Sejahtra Tbk. pada tahun 2019. Nilai maksimum sebesar 0,5555, memiliki arti bahwa aset tetap yang dimiliki perusahaan sebesar $55.55 \%$ dari total aset perusahaan secara keseluruhan. Perusahaan dengan nilai capital intensity maksimum adalah PT Delta Dunia Makmur Tbk. di tahun 2018. Nilai rata-rata (mean) variabel capital intensity sebesar 0,263284 dan nilai standar deviasi sebesar 0,1194006 menunjukkan bahwa standar penyimpangan data terhadap nilai rata-ratanya sebesar 0,1194006

Variabel Investment Opportunity Set $\left(\mathrm{X}_{3}\right)$, investment Opportunity Set (IOS) adalah nilai sekarang atas pilihan investasi di masa yang akan datang. IOS dalam penelitian ini diukur dengan menggunakan market-to-book assets ratio. Berdasarkan hasil uji statistik deskriptif dari 44 sampel penelitian diperoleh nilai minimum IOS sebesar 0,5593 dan nilai maksimumnya 2,2019. Perusahaan dengan IOS terendah dalam penelitian ini adalah PT Dian Swastatika Sentosa Tbk. pada tahun 2018. Perusahaan dengan IOS tertinggi pada penelitian ini adalah PT Bukit Asam Tbk. tahun 2018. Nilai rata-rata (mean) IOS yang dimiliki oleh perusahaan dalam penelitian ini adalah sebesar 1,156734 atau sebesar 1,16 persen. Standar deviasi dari IOS sebesar 0,4089052 menunjukkan bahwa standar penyimpangan data terhadap nilai rata-ratanya sebesar 0,4089052 .

Uji normalitas bertujuan untuk mengetahui apakah data yang digunakan dalam model regresi memiliki distribusi normal atau tidak. Uji normalitas dilakukan dengan menggunakan uji OneSample Kolmogorov-Smirnov (K-S) dengan tingkat signifikan $\alpha=0,05$ (5\%). Data dapat dikatakan berdistribusi normal apabila nilai Asymp Sig. (2-tailed) lebih besar dari 0,05. Hasil uji normalitas menunjukkan bahwa nilai Asymp. Sig. (2-tailed) yang dihasilkan adalah sebesar 0,200. Nilai yang dihasilkan ini lebih besar dari signifikan 0,05 sehingga dapat disimpulkan seluruh variabel dalam model persamaan regresi penelitian ini sudah berdistribusi secara normal.

Uji multikolinieritas bertujuan untuk mendeteksi apakah dalam model regresi terdapat korelasi antar variabel bebas atau tidak. Untuk mengetahui adanya gejala multikolinieritas pada penelitian ini adalah dengan melihat nilai tolerance dan Variance Inflaction Factor (VIF). Hasil uji multikolinearitas menunjukkan bahwa untuk semua variabel independen yang digunakan memiliki nilai tolerance lebih besar dari 0,10 dan nilai VIF kurang dari 10, sehingga dapat disimpulkan bahwa tidak terjadi multikolinearitas antar variabel independent.

Uji heteroskedasitas digunakan untuk mengetahui apakah model regresi ada ketidaksamaan varian dari residual semua pengamatan pada model regresi. Uji heterokedastisitas dilakukan dengan uji rank spearman. Apabila nilai signifikan lebih besar dari 0,05 maka model regresi dikatakan bebas dari heterokedastisitas. Hasil uji hesteroskedastisitas menunjukkan tingkat signifikansi ketiga variabel lebih besar dari 0,05 sehingga dapat disimpulkan bahwa model regresi yang digunakan pada penelitian ini tidak mengandung gejala heteroskedastisitas.

Uji autokorelasi bertujuan untuk mendeteksi adanya korelasi atau pengaruh data dari pengamatan sebelumnya dalam suatu model regresi. Untuk menguji ada atau tidaknya autokorelasi 
pada penelitian ini menggunakan uji Durbin-Watson. Hasil uji autokorelasi pada penelitian ini memperoleh nilai Durbin Watson (DW) sebesar 2,072 dengan $\mathrm{n}$ sebanyak 44 observasi dan $\mathrm{k}=3$. Kriteria yang terpenuhi yaitu $\mathrm{dU}<\mathrm{DW}<4$-dU sehingga dapat disimpulkan bahwa model regresi bebas dari gejala autokorelasi.

Tabel 3.

Hasil Analisis Regresi Linear Berganda

\begin{tabular}{lrrrrr}
\hline \multirow{2}{*}{ Model } & \multicolumn{2}{c}{$\begin{array}{c}\text { Unstandardized } \\
\text { Coefficients }\end{array}$} & $\begin{array}{c}\text { Standardized } \\
\text { Coefficients }\end{array}$ & t & Sig. \\
\cline { 2 - 4 } & B & $\begin{array}{c}\text { Std. } \\
\text { Error }\end{array}$ & Beta & & \\
\hline (Constant) & 0,382 & 0,089 & & & \\
Konservatisme Akuntansi & $-0,111$ & 0,339 & $-0,048$ & $-0,329$ & 0,000 \\
Capital Intensity & 0,432 & 0,189 & 0,328 & 2,277 & 0,028 \\
Investment Opportunity Set & -0.114 & 0,055 & $-0,298$ & $-2,089$ & 0,043 \\
\hline \multicolumn{1}{c}{ Sumber: Data diolah, 2021 } & & & & &
\end{tabular}

Sumber: Data diolah, 2021

Nilai konstanta 0,382 menunjukkan bahwa bila nilai seluruh variabel bebas sama dengan nol, maka tax avoidance akan bernilai sebesar 0,382 satuan. Nilai koefisien $\left(\beta_{1}\right)$ variabel konservatisme akuntansi $\left(\mathrm{X}_{1}\right)$ sebesar $-0,111$ menunjukkan bahwa apabila konservatisme akuntansi naik satu satuan, maka tax avoidance akan mengalami penurunan sebesar -0,111 satuan dengan asumsi variabel lainnya konstan. Nilai koefisien $\left(\beta_{2}\right)$ variabel capital intensity $\left(X_{2}\right)$ sebesar 0,431 menunjukkan bahwa apabila capital intensity naik satu satuan, maka tax avoidance akan mengalami peningkatan sebesar 0,431 satuan dengan asumsi variabel lainnya konstan. Nilai koefisien $\left(\beta_{3}\right)$ variabel investment opportunity set $\left(\mathrm{X}_{3}\right)$ sebesar - 0,114 menunjukkan bahwa apabila investment opportunity set naik satu satuan, maka tax avoidance akan mengalami penurunan sebesar 0,114 satuan dengan asumsi variabel lainnya konstan.

Berdasarkan hasil pengujian diperoleh nilai adjusted $\mathrm{R}^{2}$ sebesar 0,148 yang berarti bahwa $14,8 \%$ variasi dari tax avoidance $(\mathrm{Y})$ dapat dijelaskan oleh variabel konservatisme akuntansi $\left(\mathrm{X}_{1}\right)$, capital intensity $\left(\mathrm{X}_{2}\right)$ dan investment oppotubity set $\left(\mathrm{X}_{3}\right)$. Sisanya sebesar 85,2\% dijelaskan oleh variabel-variabel lain yang tidak dimasukkan dalam model regresi.

Berdasarkan hasil pengujian diperoleh nilai $\mathrm{F}$ hitung sebesar 3,486 dengan nilai signifikansi $\mathrm{F}$ sebesar 0,024 yang lebih kecil dari $\alpha=0,05$, ini berarti model yang digunakan pada penelitian ini adalah layak untuk digunakan sebagai alat analisis untuk menguji pengaruh variabel independen terhadap variabel dependen.

Hipotesis pertama $\left(\mathrm{H}_{1}\right)$ dalam penelitian ini menyatakan konservatisme akuntansi berpengaruh positif pada tax avoidance. Berdasarkan hasil analisis regresi linear berganda, diperoleh nilai koefisien beta negatif sebesar 0,111 dengan tingkat signifikansi sebesar 0,744 yang lebih besar dari tingkat taraf nyata penelitian yaitu $0,05(5 \%)$. Hal itu menunjukkan bahwa tingkat konservatisme akuntansi tidak berpengaruh pada tax avoidance. Penggunaan metode akuntansi yang konservatif tidak akan meningkatkan kecenderungan perusahaan untuk melakukan tax avoidance. Hal ini menunjukkan bahwa $\mathrm{H}_{1}$ dalam penelitian ini ditolak.

Hasil penelitian ini sejalan dengan penelitian Pramudito \& Sari (2015), Sari dkk. (2016) serta Susanti (2018) yang mendapatkan hasil konservatisme akuntansi tidak berpengaruh pada tax avoidance. Hasil penelitian ini menunjukan bahwa konservatisme akuntansi bukanlah variabel penyebab yang mempengaruhi perusahaan untuk melakukan tax avoidance. Hal ini disebabkan karena peraturan perpajakan di Indonesia dapat mengantisipasi prinsip konservatisme yang masih dipegang

Pengaruh Konservatisme Akuntansi, Capital Intensity, dan Investment Opportunity Set pada Tax Avoidance, Desi Kusuma Dewi dan Naniek Noviari 
oleh beberapa perusahaan. Hal tersebut dapat terlihat pada beberapa kebijakan pemerintah mengenai perpajakan seperti tidak diperkenankannya membentuk cadangan piutang ragu-ragu sebagai pengurang penghasilan kena pajak dan hanya boleh menggunakan metode harga perolehan secara rata-rata atau dengan cara mendahulukan persediaan yang diperoleh pertama (FIFO) serta tidak boleh menggunakan LIFO untuk menilai persediaan dan pemakaian persediaan untuk perhitungan harga pokok. Jika merujuk pada peraturan tersebut, dapat dikatakan bahwa prinsip konservatisme akuntansi sudah tidak bisa lagi digunakan sebagai alasan untuk mengurangi besaran tarif pajak efektif yang dikeluarkan wajib pajak atau perusahaan.

Hipotesis kedua $\left(\mathrm{H}_{2}\right)$ dalam penelitian ini menyatakan bahwa capital intensity berpengaruh positif pada tax avoidance. Berdasarkan hasil analisis regresi linear berganda, diperoleh nilai koefisien beta positif sebesar 0,432 dengan tingkat signifikansi sebesar 0,028 yang lebih kecil dari tingkat taraf nyata penelitian yaitu $0,05(5 \%)$. Hal itu menunjukkan bahwa tingkat capital intensity berpengaruh positif tax avoidance. Investasi perusahaan pada aset tetap menyebabkan timbulnya beban depresiasi. Beban depresiasi akan mempengaruhi pajak perusahaan, hal ini dikarenakan beban depresiasi akan bertindak sebagai pengurang laba yang menyebabkan rendahnya pajak terhutang perusahaan. Semakin tinggi capital intensity perusahaan maka tindakan tax avoidance yang dilakukan oleh perusahaan semakin tinggi. Hal ini menunjukkan bahwa $\mathrm{H}_{2}$ dalam penelitian ini diterima.

Hasil penelitian ini sejalan dengan penelitian yang dilakukan oleh Richardson \& Lanis (2007), Noor et al. (2010), Anindyka dkk. (2018), serta Dwiyanti \& Jati (2019) yang membuktikan bahwa capital intensity berpengaruh positif pada tax avoidance. Hasil penelitian ini juga mendukung theory of planed behavior. Niat dalam berperilaku muncul karena keyakinan tentang harapan normatif orang lain. Dalam hal ini, pihak manajemen memiliki keyakinan tetang harapan prinsipal untuk memperoleh laba tinggi dengan pengeluaran beban pajak serendah mungkin, sehingga manajemen termotivasi untuk memenuhi harapan tersebut. Beban penyusutan aset tetap perusahaan dapat dimanfaatkan oleh manajer untuk meminimumkan pajak yang dibayarkan perusahaan. Perusahaan yang memutuskan untuk berinvestasi dalam bentuk aset tetap dapat menjadikan biaya penyusutan sebagai biaya yang dapat dikurangkan dari penghasilan dan akan menyebabkan laba kena pajak perusahaan menjadi berkurang yang pada akhirnya akan mengurangi jumlah kena pajak yang harus dibayar oleh perusahaan.

Hipotesis ketiga $\left(\mathrm{H}_{3}\right)$ dalam penelitian ini menyatakan bahwa investment opportunity set berpengaruh negatif pada tax avoidance. Berdasarkan hasil analisis regresi linear berganda, diperoleh nilai koefisien beta negatif sebesar 0,114 dengan tingkat signifikansi sebesar 0,043 yang lebih kecil dari tingkat taraf nyata penelitian yaitu $0,05(5 \%)$. Hal itu menunjukkan bahwa tingkat bahwa investment opportunity set berpengaruh negatif pada tax avoidance. Perusahaan yang bertumbuh akan lebih mementingkan angka-angka akuntansi yang bagus daripada melakukan penghematan pajak (Lubis dkk., 2017). Perusahaan dengan investment opportunity set yang tinggi berarti lebih memanfaatkan peluang investasinya dan berusaha mendapakan keuntungan yang besar dari investasi tersebut. Semakin besar pendapatan yang didapatkan perusahaan dari investasi tersebut maka akan meningkatkan pajak perusahaan. Semakin tinggi investment opportunity set perusahaan maka tindakan tax avoidance yang dilakukan oleh perusahaan semakin rendah. Hal ini menunjukkan bahwa $\mathrm{H}_{3}$ dalam penelitian ini diterima.

Hasil penelitian ini sejalan dengan penelitian yang dilakukan oleh Ruba'i (2009) serta Firmansyah \& Bayuaji (2019) yang membuktikan bahwa investment opportunity set berpengaruh negatif pada tax avoidance. Hasil penelitian ini juga mendukung teori agensi. Teori agensi memiliki asumsi bahwa tiap-tiap individu semata-mata termotivasi oleh kepentingan dirinya sendiri sehingga 
menimbulkan konflik kepentingan antara principal dan agent yang sering disebut masalah keagenan (agency problem). IOS dianggap sebagai salah satu aktivitas perusahaan yang dapat meminimalkan masalah keagenan (Firmansyah dan Bayuaji, 2019). IOS yang tinggi akan membuat manajer (agent) memiliki peluang yang sangat baik untuk memilih berbagai pilihan investasi sehingga sejalan dengan kepentingan pemilik perusahaan (principal) yang menginginkan tambahan kekayaan dalam jangka panjang. Perusahaan yang memiliki banyak alternatif investasi di masa depan akan lebih sedikit berinvestasi dalam aktivitas penghindaran pajak (McGuire et al., 2014). Hal tersebut dikarenakan perusahaan sudah memiliki alternatif investasi yang pengembaliannya melebihi manfaat dari penghindaran pajak. Oleh karena itu, perusahaan dengan IOS tinggi memiliki probabilitas yang lebih kecil untuk melakukan tax avoidance.

\section{SIMPULAN DAN SARAN}

Berdasarkan hasil pembahasan maka dapat disimpulkan bahwa konservatisme akuntansi tidak berpengaruh pada tax avoidance. Hasil ini menunjukan bahwa konservatisme akuntansi bukanlah variabel penyebab yang mempengaruhi perusahaan untuk melakukan tax avoidance. Hal ini disebabkan karena peraturan perpajakan di Indonesia dapat mengantisipasi prinsip konservatisme yang masih dipegang oleh beberapa perusahaan; capital intensity berpengaruh positif pada tax avoidance. Hasil ini dapat diartikan semakin tinggi capital intensity perusahaan maka tindakan tax avoidance yang dilakukan oleh perusahaan semakin tinggi. Investasi perusahaan pada aset tetap menyebabkan timbulnya beban depresiasi. Beban depresiasi akan mempengaruhi pajak perusahaan, hal ini dikarenakan beban depresiasi akan bertindak sebagai pengurang laba yang menyebabkan rendahnya pajak terhutang perusahaan; investment opportunity set berpengaruh negatif pada tax avoidance. Hasil ini menunjukkan bahwa perusahaan dengan investment opportunity set yang tinggi berarti lebih memanfaatkan peluang investasinya dan berusaha mendapakan keuntungan yang besar dari investasi tersebut. Semakin besar pendapatan yang didapatkan perusahaan dari investasi tersebut maka akan meningkatkan pajak perusahaan. Semakin tinggi investment opportunity set perusahaan maka tindakan tax avoidance yang dilakukan oleh perusahaan semakin rendah.

Berdasarkan hasil penelitian dan simpulan diatas, maka dapat diajukan saran bagi perusahaan diharapkan dapat memperhatikan setiap keputusan yang akan diambil agar sesuai dengan peraturan perpajakan yang berlaku. Selain itu, perusahaan sebaiknya juga berhati-hati dalam menentukan kebijakan, khususnya mengenai pajak agar tidak tergolong kedalam tindakan penggelapan pajak (tax evasion) karena akan merugikan perusahaan dan mendapatkan sanksi yang dapat mengakibatkan menurunnya reputasi perusahaan terutama dimata investor dan lingkungan masyarakat. Hasil uji koefisien determinasi dalam penelitian ini menunjukan bahwa 14,1\% tingkat tax avoidance yang terjadi pada perusahaan pertambangan dipengaruhi oleh konservatisme akuntansi, capital intensity, dan investment opportunity set. Bagi penelitian selanjutnya dapat meneliti variabel lain yang mungkin dapat memengaruhi tax avoidance seperti good corporate governance, leverage, dan arus kas operasi.

\section{REFERENSI}

Adi, G. K., \& Mildawati, T. (2018). Pengaruh Konservatisme Akuntansi, Leverage, Profitabilitas, Ukuran Perusahaan dan Kompensasi Rugi Fiksal terhadap Tax Avoidance. Jurnal Ilmu Dan Riset Akuntansi, 7 , 
$1-20$.

Anindyka, D., Pratomo, D., \& Kurnia. (2018). Pengaruh Leverage (DAR), Capital Intensity dan Inventory Intensity terhadap Tax Avoidance. E-Proceeding of Management, 5(1), 713-719.

Artinasari, N., \& Mildawati, T. (2018). Pengaruh Profitabilitas, Leverage, Likuiditas, Capital Intensity dan Inventory terhadap Tax Avoidance. Jurnal Ilmu Dan Riset Akuntansi, 7(8), 1-18.

Azharuddin. (2016). Pengaruh Kecakapan Manajerial, Set Kesempatan Investasi, Intensitas Modal, dan Konservatisme Akuntansi terhadap Tarif Pajak Efektif Perusahaan. Fakultas Ekonomi Universitas Negeri Jakarta.

Cahya Dewanti, I. G. A. D., \& Sujana, I. K. (2019). Pengaruh Ukuran Perusahaan, Corporate Social Responsibility, Profitabilitas dan Leverage pada Tax Avoidance. E-Jurnal Akuntansi, 28(1), 377-406. https://doi.org/10.24843/eja.2019.v28.i01.p15

Dwiyanti, I. A. I., \& Jati, I. K. (2019). Pengaruh Profitabilitas, Capital Intensity, dan Inventory Intensity pada Penghindaran Pajak. E-Jurnal Akuntansi Universitas Udayana, 27(3), 2293-2321. https://doi.org/10.24843/eja.2019.v27.i03.p24

Firmansyah, A., \& Bayuaji, R. (2019). Financial Constraints, Investment Opportunity Set, Financial Reporting Aggressiveness, Tax Aggressiveness: Evidence From Indonesia Manufacturing Companies. Academy of Accounting and Financial Studies Journal, 23(5), 1-18.

Givoly, D., \& Hayn, C. (2000). The changing time-series properties of earnings, cash flows and accruals: Has financial reporting become more conservative? Journal of Accounting and Economics, 29(3), 287-320.

Jama', A. K., \& Harnovinsah. (2017). Pengaruh Faktor Keungan dan Intensitas Aset Tetap terhadap Keputusan Pelaporan Keungan dan Pajak. Profita: Komunikasi Ilmiah Dan Perpajakan, 10(2), 327-345.

Lubis, E. M., Yusralaini, \& Rusli. (2017). Pengaruh Set Kesempatan Investasi, Profitabilitas, Kepemilikan Pemerintah, dan Fasilitas Perpajakan terhadap Tarif Pajak Efektif Perusahaan yang Terdaftar pada Kompas 100. Jurnal Online Mahasiswa Fakultas Ekonomi, 3(1), 1-14.

Maitriyadewi, N. L. R. P., \& Noviari, N. (2020). Manajemen Laba, Profitabilitas dan Kepemilikan Keluarga dan Tax Avoidance. E-Jurnal Akuntansi, 30(6), 1382. https://doi.org/10.24843/eja.2020.v30.i06.p04

McGuire, S. T., Omer, T. C., \& Wilde, J. H. (2014). Investment Opportunity Sets, Operating Uncertainty, and Capital Market Pressure: Determinants of Investments in Tax Shelter Activities? Journal of the American Taxation Association, 36(1), 1-26. https://doi.org/10.2308/atax-50599

Muzakki, M. R., \& Darsono. (2015). Pengaruh Corporate Social Responsibility dan Capital Intensity terhadap Penghindaran Pajak. Diponegoro Journal of Accounting, 4(3), 1-8.

Noor, R. M., Fadzillah, N. S. M., \& Mastuki, N. (2010). Corporate Tax Planning: A Study On Corporate Effective Tax Rates of Malaysian Listed Companies. International Journal of Trade, Economics and Finance, 1(2), 189-193. https://doi.org/10.7763/IJTEF.2010.V1.34

Pramudito, B. W., \& Sari, M. M. R. (2015). Pengaruh Konservatisme Akuntansi, Kepemilikan Manajerial dan Ukuran Dewan Komisaris terhadap Tax Avoidance. E-Jurnal Akuntansi, 13(3), 737-752.

Putra, P. dwi, Syah, D. husrizal, \& Sriwedari, sriwedari. (2018). Tax Avoidnce: Evidence of As a proof of Agency Theory and Tax Planning. International Journal of Research \& Review, 5(9), 52-60. https://doi.org/10.1107/s0108768109011057

Richardson, G., \& Lanis, R. (2007). Determinants of the variability in corporate effective tax rates and tax reform: Evidence from Australia. Journal of Accounting and Public Policy, 26(6), 689-704. https://doi.org/10.1016/j.jaccpubpol.2007.10.003

Rosdiani, N., \& Hidayat, A. (2020). Pengaruh Derivatif Keuangan, Konservatisme Akuntansi dan Intensitas Aset Tetap terhadap Penghindaran Pajak. Journal of Technopreneurship on Economics and Business Review, $1(1), 131-143$.

Ruba'i, A. (2009). Pengaruh Kecakapan Manajerial dan Set Kesempatan Investasi (IOS) terhadap Tarif Pajak Efektif. Universitas Gadjah Mada.

Sari, N., Kalbuana, N., \& Jumadi, A. (2016). Pengaruh Konservatisme Akuntansi, Kualitas Audit, Ukuran Perusahaan terhadap Penghindaran Pajak. Syariah Paper Accounting FEB UMS, 431-440.

Sundari, N., \& Aprilina, V. (2017). Pengaruh Konservatisme Akuntansi, Intensitas Aset Tetap, Kompensasi Rugi Fiskal Dan Corporate Governanace Terhadap Tax Avoidance. Jurnal Riset Akuntansi Dan Komputerisasi Akuntansi, 8(1), 85-109. https://doi.org/10.33558/jrak.v8i1.861

Susanti, C. M. (2018). Pengaruh Konservatisme, Leverage, Profitabilitas, Ukuran Perusahaan Terhadap Tax Avoidance. Jurnal Informasi Perpajakan, Akuntansi Dan Keuangan Publik, 13(2), 181-198.

Wiguna, I. P. P., \& Jati, I. K. (2017). Pengaruh Corporate Social Responsibility, Preferensi Risiko Eksekutif, dan Capital Intensity pada Penghindaran Pajak. E-Jurnal Akuntansi, 21(1), 418-446.

Xynas, L. (2011). Tax Planning, Avoidance and Evasion in Australia 1970-2010: The Regulatory Responses and

Pengaruh Konservatisme Akuntansi, Capital Intensity, dan Investment Opportunity Set pada Tax Avoidance, 
Taxpayer Compliance. Revenue Law Journal, 20(1), 1-37.

Yulistian, A., Nasir, A., \& Hasan, M. A. (2018). Pengaruh Corporate Governance dan Konservatisme Akuntansi terhadap Tax Avoidance. Jurnal Online Mahasiswa Fakultas Ekonomi, 1(1), 1-13. 